\title{
Swyer-James-MacLeod syndrome: an important differential diagnosis in adulthood
}

\author{
Carla Pereira Fontes (1), ${ }^{1}$ Marta Reis de Sousa ${ }^{2}$
}

${ }^{1}$ Internal Medicine, Centro Hospitalar de Entre o Douro e Vouga EPE, Santa Maria da Feira, Portugal

${ }^{2}$ Radiology, Centro Hospitalar de Entre o Douro e Vouga EPE, Santa Maria da Feira, Portugal

\section{Correspondence to} Dr Carla Pereira Fontes; carla.pfts@gmail.com

Accepted 2 September 2021

Check for updates

(c) BMJ Publishing Group Limited 2021. No commercial re-use. See rights and permissions. Published by BMJ.

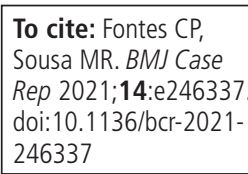

\section{DESCRIPTION}

A 34-year-old man with a history of pulmonary tuberculosis in early adolescence presented to the emergency department with a 3-month history of relapsing fever, right-sided pleuritic thoracalgia and productive cough with purulent sputum. $\mathrm{He}$ had already received several courses of antibiotics with recurrence of symptoms. Chest examination revealed decreased breath sounds over the upperright lung, but no crackles or wheezing; there was no peripheral oedema. Laboratory studies showed neutrophilic leucocytosis (total leucocyte count of $22.6 \times 10^{9} / \mathrm{L}$ and absolute neutrophil count of $\left.21.24 \times 10^{9} / \mathrm{L}\right)$ and elevated $\mathrm{C}$ reactive protein $(373$ $\mathrm{mg} / \mathrm{L})$. Chest radiograph revealed a hyperlucent right upper lobe with ipsilateral opacities (figure 1), and contrast CT confirmed confluent densifications associated with reduced pulmonary vasculature and increased lucency of the right upper lobe (figure 2). These particular findings (unilateral hyperlucency and corresponding decreased ventilation and perfusion) were already present on previous imaging examinations, but were disregarded. A bronchoscopy with biopsy was performed and endobronchial abnormalities were excluded. Cultures of sputum and bronchoalveolar lavage were negative, including for Mycobacterium. The patient was given a broad-spectrum antibiotic with a favourable response. Further pulmonary ventilation/perfusion scintigraphy (VPS) revealed a matched ventilation and perfusion defect of the affected area. Based on the clinical presentation and investigations, the diagnosis of Swyer-James-MacLeod syndrome (SJMS) was established.

SJMS is a rare complication of recurrent pulmonary infections in childhood, most commonly obliterative bronchiolitis. Various infectious agents are

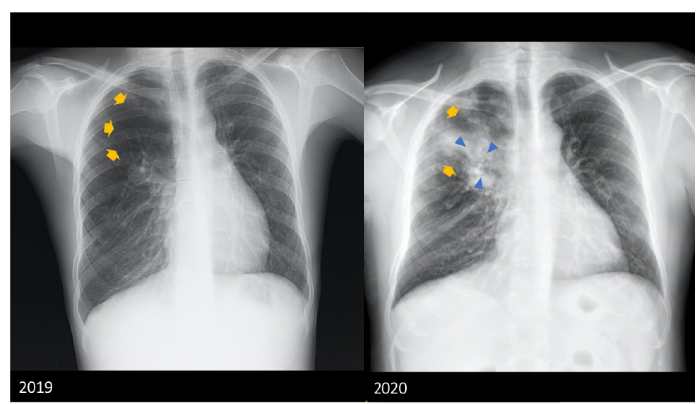

Figure 1 Posteroanterior view of chest radiograph showing right upper lobe hyperlucency (yellow arrows) at the onset of symptoms (2019) and 3 months later on hospital admission (2020), associated with ipsilateral opacities (blue arrows) compatible with active infection.

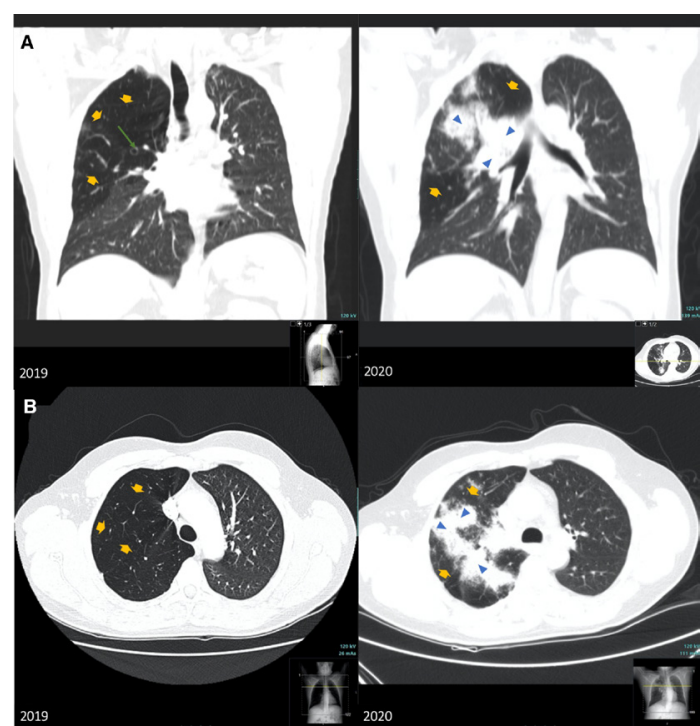

Figure 2 CT ((A) coronal and (B) axial views) demonstrating decreased attenuation of the upper right lobe with signs of air tripping, marked hypoperfusion (yellow arrows) and bronchiectasis (green arrow) at the onset of symptoms (2019) and 3 months later on hospital admission (2020). Confluent opacities (blue arrows) compatible with active infection are shown in the rightsided images.

implicated, including viruses (measles, respiratory syncytial virus, influenza A) and bacteria (Bordetella pertussis, Mycoplasma pneumoniae, Mycobacterium tuberculosis). ${ }^{1}$ The injury to the bronchiolar epithelium triggers an inflammatory response that leads to the development of submucosal fibrosis and destruction of the alveolar wall, causing airflow limitation and obstruction of the pulmonary capillary bed. ${ }^{2}$ This functional hypoplasia of the bronchial vasculature may impair the growth of the affected lung, leading to a lung of preserved or slightly reduced size.

In most cases, diagnosis occurs in childhood, but some patients remain asymptomatic until adulthood, when SJMS has a variable spectrum of manifestations, ranging from recurrent respiratory infections to productive cough, exertional dyspnoea or haemoptysis; occasionally it is an incidental imaging finding. ${ }^{4}$ The differential diagnosis includes both congenital and acquired lung disorders (pulmonary agenesis, aplasia or hypoplasia, congenital lobar or localised interstitial emphysema, pneumothorax). ${ }^{23}$ The characteristic radiological pattern is defined by a hyperlucency associated with decreased pulmonary vascularity, expiratory air trapping and hyperinflation, which may be confined to one lung or lobe. ${ }^{25}$ 
In some patients, bronchiectasis may be present and influence the clinical course and prognosis. ${ }^{3}$ Although a posteroanterior chest radiography is usually the first test performed, CT is the most sensitive and valuable imaging method for the evaluation of the lung involvement. ${ }^{5}$ A VPS may be useful to assess the extent of the disease. ${ }^{4} \mathrm{CT}$ and resonance magnetic angiographies are other diagnostic modalities for SJMS. ${ }^{3}$

Conservative management based on prevention (pneumococcal and influenza vaccination) and prompt treatment of recurrent respiratory infections is the mainstay of therapy, but lung volume reduction surgery may be considered in certain cases. ${ }^{2}$

\section{Learning points}

Swyer-James-MacLeod syndrome (SJMS) is a rare lung disease, considered a consequence of recurrent respiratory infections in childhood.

- Because of its characteristic radiological pattern, SJMS is often referred to as unilateral hyperlucent lung syndrome due to distension of the alveoli in conjunction with decreased parenchymal perfusion.

- Prompt recognition of this entity, especially in adulthood, is crucial, as it can mimic other pulmonary diseases and lead to misdiagnosis and an inappropriate approach.
Careful clinical and imaging assessment allows for a correct diagnosis, which is paramount when SJMS is suspected.

Contributors CPF was involved in drafting the article. MRdS was involved in selecting the images and revising the article critically for important intellectual content. All authors read and approved the final manuscript.

Funding The authors have not declared a specific grant for this research from any funding agency in the public, commercial or not-for-profit sectors.

Competing interests None declared.

Patient consent for publication Obtained.

Provenance and peer review Not commissioned; externally peer reviewed.

\section{ORCID iD}

Carla Pereira Fontes http://orcid.org/0000-0002-9697-826X

\section{REFERENCES}

1 Sen HS, Taylan M, Abakay O, et al. Adult diagnosis of Swyer-James-Macleod syndrome: retrospective analysis of four cases. Respir Care 2014;59:e51-4.

2 Dirweesh A, Alvarez C, Khan M, et al. A unilateral hyperlucent lung - SwyerJames syndrome: a case report and literature review. Respir Med Case Rep 2017:20:104-6.

3 Mehra S, Basnayake T, Falhammar H, et al. Swyer-James-MacLeod syndrome-a rare diagnosis presented through two adult patients. Respirol Case Rep 2017;5:e00245.

4 Abba AA, Al-Mobeireek AF. Clinical spectrum of Swyer-James-Macleod syndrome in adults. Saudi Med J 2003;24:195-8.

5 Moore AD, Godwin JD, Dietrich PA, et al. Swyer-James syndrome: CT findings in eight patients. AJR Am J Roentgenol 1992;158:1211-5.

Copyright 2021 BMJ Publishing Group. All rights reserved. For permission to reuse any of this content visit https://www.bmj.com/company/products-services/rights-and-licensing/permissions/

BMJ Case Report Fellows may re-use this article for personal use and teaching without any further permission.

Become a Fellow of BMJ Case Reports today and you can:

- Submit as many cases as you like

- Enjoy fast sympathetic peer review and rapid publication of accepted articles

- Access all the published articles

- Re-use any of the published material for personal use and teaching without further permission

\section{Customer Service}

If you have any further queries about your subscription, please contact our customer services team on +44 (0) 2071111105 or via email at support@bmj.com.

Visit casereports.bmj.com for more articles like this and to become a Fellow 